\title{
CLINICAL CHARACTERISTICS OF PAEDIATRIC MEASLES PATIENTS AT MOJOWARNO CHRISTIAN HOSPITAL, JOMBANG, IN 2015-2016
}

\author{
Received: 08-04-2020 • Accepted: 17-07-2020 \\ http://dx.doi.org/10.21460/bikdw.v5i1.139
}
Yuda Pradana, Fransiskus Xaverius Wikan Indrarto, Maria Silvia Merry, Yoseph Leonardo Samodra

Faculty of Medicine, Universitas Kristen Duta Wacana, Yogyakarta, Indonesia Correspondence: pradanayuda19@gmail.com

\begin{abstract}
Background: Measles is one of the main causes of child mortality. In 2016 there were 6,890 cases of measles with 4 patients died in Indonesia. There were 122 cases in Jombang, East Java in 2009.

Aim: To describe the clinical characteristics of measles in children patients at Mojowarno Christian Hospital, Jombang, East Java.

Methods: A cross sectional study using secondary data from medical records at Mojowarno Christian Hospital, Jombang, East Java, in 2015-2015. Demographic and clinical characteristics were described using tables.

Results: There are 22 cases of measles in children, 3 of them had not taken measles vaccination. Most cases occurred in between 0 to 5 years old (59.1\%). The proportion of measles were equal between male and female. There is a higher proportion of patients with normal nutrition status (59.1\%) compared to other with malnutrition (40.9\%). The most common symptoms and signs are fever $(95.5 \%)$, cough $(23.7 \%)$, and coryza $(22.3 \%)$. The leukocyte examination mostly shows normal results for leukocyte (63.6\%) and lymphocyte (50\%).

Conclusion: Most of the cases were presented with milder symptoms, signs and laboratory examination. There is a high prevalence of undernutrition among the subjects, which need further attention from local governments. In addition, there is a concerning high proportion of vaccinated children contracting the disease.
\end{abstract}

Keywords: measles, nutritional status, Jombang, child, adolescent 


\section{INTRODUCTION}

Measles, or morbilli, is a viral infection, caused by morbillivirus. The infection is commonly divided into 4 stages which are incubation, prodromal, exanthema, and convalescence. The incubation period of measles infection takes 8 to 12 days with main entry points from the respiratory tract. The prodromal clinical manifestation usually takes 3 days are high fever, cough, coryza, and conjunctivitis, and by a pathognomonic sign of Koplik spots in the mucosa of the mouth cavity. The prodromal symptoms continue in the subsequent stage, where an exanthema skin rash appears on the forehead and spreads to the torso and extremities. In the last stage, the rash fades and followed by symptoms regression. ${ }^{1,2}$

Children aged 1 to 9 years old have the highest risk of contracting measles. ${ }^{3}$ Children with malnutrition, not vaccinated and lack of breastmilk provision are more susceptible to measles infections compared to previously healthy ones. ${ }^{4}$ In some cases, measles infection might be complicated by gastroenteritis, bronchiolitis, otitis media, and encephalopathy. Those complications might be influenced by the patient's age, malnutrition, immunodeficiency, and environmental condition (i.e. population density). ${ }^{5}$

Measles is still a common cause of death in Indonesian children in the past decade, despite the vaccine availability and safety. In 2015 , there were 134,200 measles fatalities worldwide, while in 2016 there were 6,890 measles cases with
4 fatalities in Indonesia. ${ }^{4,6}$ The most recent data to date for the Jombang municipality was from 2009, with 122 measles cases. Jombang has about $90 \%$ coverage of measles vaccination. ${ }^{7}$ Mojowarno Christian Hospital is one of the hospitals in Jombang treating measles patients. This study is aimed to describe the clinical characteristics of measles in children treated at Mojowarno Christian Hospital, Jombang.

\section{METHODS}

This is a cross-sectional study using secondary data of paediatric measles patients at Mojowarno Christian Hospital, Jombang. The subjects were selected consecutively based on medical records from the year 2015 to 2016. Subjects included in this study are children aged 0 to 18 years old, treated at inpatient and outpatient facilities, and clinically diagnosed with measles by the attending physician. Subjects with missing data (including nutrition status, vaccination status, physical examination, and laboratory examination) were excluded from the study. The clinical characteristics were described with tables. This study has been approved by the Ethical Committee of the Faculty of Medicine, Universitas Kristen Duta Wacana.

\section{RESULTS}

During the 2015-2016 period, there are 22 measles cases in children treated at Mojowarno Christian Hospital, Jombang. Table 1 described the demographic characteristics of the subjects. 
Table 1. Demographic characteristic of paediatric measles patients at Mojowarno Christian Hospital in 2015-2016 (n=22)

\begin{tabular}{lr}
\hline Characteristics & n (\%) \\
\hline Sex & $11(50.0 \%)$ \\
Male & $11(50.0 \%)$ \\
Female & \\
\hline Age groups & $13(59.1 \%)$ \\
$0-5$ years old & $6(27.3 \%)$ \\
$5-10$ years old & $3(13.6 \%)$ \\
$10-17$ years old & \\
\hline
\end{tabular}

\section{Clinical Characteristics}

Table 2 shows the clinical characteristics of the cases, which include nutritional status, vaccination status. symptoms and signs, and results of laboratory examination. There is a high proportion of undernutrition, with fever as the most common symptom. The laboratory examination shows abnormal leukocyte and lymphocyte results in $36.4 \%$ and $50 \%$ of patients, respectively. Five cases with complications (which are bronchiolitis and gastroenteritis) all affect children in the 0 to 5 years old age group.

\section{DISCUSSION}

This study appropriately used a cross-sectional design to describe the clinical characteristics of measles patients. However, the limited study centre in one hospital has raised selection bias, where patient or family preference of hospital facilities might cause the higher vaccination status among the patients.

\section{Demographic Characteristics and Measles Susceptibily}

The highest proportion of cases in 0 to 5 years old age group is concordant with the national health report in 2015. ${ }^{3}$ Other studies in Cirebon,
Manado, and Bandung confirm the higher prevalence on under five age groups, with a shift to older years (5 to 9 years old) in areas with high vaccination rates. ${ }^{8-10}$ The susceptibility in children under five years old might be explained by decreasing level of maternal antibody before regular measles vaccination at 6 years old. 10

Among the under five patients, there are five children (38.5\%) with complications (bronchiolitis and gastroenteritis). Bronchiolitis is usually caused by superinfection with S. pneumoniae, H. influenzae, or S. aureus, where gastroenteritis is resulted from morbillivirus infection on gastrointestinal tract epithelial cells, which causing necrosis and giant cell formation along the gastrointestinal tract. Furthermore, severe gastroenteritis might cause dehydration. ${ }^{2}$ The complications found in this study are similar to another research in Manado. ${ }^{9}$ Interestingly, other research has discovered that measles was one of the common cause of on bronchiolitis and gastroenteritis among children.11,12 Aside from the decreasing maternal antibody, other risk factors that should be considered are immunodeficiency, malnutrition (including vitamin $\mathrm{A}$ and zinc deficiency), and housing within densely populated areas. ${ }^{2}$

This study found that there is no higher susceptibility in either sex. There are conflicting evidences, where sex is not related with measles susceptibility and findings of higher proportion in male patients. 8,13 The later argued that female children had higher rates of antibody against measles compared to the male ones. However, neither of the studies showed any difference in mortality between males and females. 
Table 2. Clinical characteristic of paediatric measles patients at Mojowarno Christian Hospital in 2015-2016 (n=22)

\begin{tabular}{lr}
\hline Characteristics & \multicolumn{1}{c}{$\mathbf{N}(\%)$} \\
\hline Nutritional Status & \\
$\quad$ Undernutrition & $9(40.9 \%)$ \\
$\quad$ Normal & $13(59.1 \%)$ \\
Vaccination status & \\
Complete & $19(86.4 \%)$ \\
No vaccination/ & $3(13.6 \%)$ \\
$\quad$ incomplete & \\
Symptoms and signs & \\
Fever & $21(95.5 \%)$ \\
Cough & $7(31.8 \%)$ \\
Conjunctivitis & $1(4.5 \%)$ \\
Diarrhoea & $1(4.5 \%)$ \\
Nausea $\&$ Vomiting & $6(27.3 \%)$ \\
Coryza & $5(22.7 \%)$ \\
Skin rash & $4(18.2 \%)$ \\
Abdominal pain & $1(4.5 \%)$ \\
Leukocyte count & \\
Leukopenia & $5(22.7 \%)$ \\
Leucocytosis & $3(13.6 \%)$ \\
Lymphopenia & $6(27.3 \%)$ \\
Lymphocytosis & $5(22.7 \%)$ \\
Complication & \\
Bronchiolitis & $1(4.5 \%)$ \\
Gastroenteritis & $4(18.2 \%)$ \\
Without complication & $17(77.3 \%)$ \\
\hline
\end{tabular}

\section{Nutritional and Vaccination Status on Measles Susceptibility}

Although the result shows a higher proportion of patients with normal nutrition status, there is quite a higher proportion of undernutrition among the patients compared to the general children population $(40.9 \%$ vs $4.78 \%$ ). ${ }^{7}$ The proportion of undernutrition in this study is also higher than other study in Bandung and Manado $(10 \%$ and $7.9 \%$, respectively), although the underweight proportion in the general population is comparatively similar between Jombang, Bandung and Manado. $7,8,9,14,15$ This difference may be due to variation in health service accessibility and undernutrition cases surrounding hospital between Jombang and other areas. Nevertheless, based on the literature, undernutrition would decrease the immune function, through reduction on delayed hypersensitivity response, T-lymphocyte count, Lymphocyte response, complement factor and cytokines, and IgA. ${ }^{16}$

In this study, there are 19 $(86.4 \%)$ patients with a history of measles vaccination. Previous studies show various proportions of vaccinated children among measles cases; $60 \%$ in Bandung, $28.4 \%$ in Manado, and $33.7 \%$ in national scale. ${ }^{9,14,17}$ On the positive side, this study shows a high proportion of measles vaccination coverage and good health-seeking behaviour of the surrounding population. On the other hand, this finding has triggered questions regarding vaccination quality, which could be caused by inappropriate administration and vaccine quality (i.e. storage and cold chain). ${ }^{18}$ Indonesia itself, has adopted measles vaccination through subcutaneous administration, while other methods (i.e. intranasal and conjunctival inoculate) are still in investigation on their efficacy and cost-efficiency. 18 Another factor that might explain this finding is age at vaccination. One systematic review shows that younger age at vaccination resulted in lower seroprotection and higher measles attack rate. ${ }^{19}$ However, discussion on this matter is limited due to lack of data regarding age at vaccination in this study.

\section{Clinical Manifestation and Laboratory Examination of Measles Cases}

The clinical characteristics of measles cases in this study resembles the literature and previous research. ${ }^{2}$ The high proportion of fever and coryza is also found in another study. ${ }^{20}$ The finding is also quite consistent with the vaccination status, where only small portions of the subjects experienced rash, cough, and coryza, 
aside from fever. Overall, milder presentation of measles is consistent with the high rate of measles vaccination among the patients. Based on literature, subclinical manifestation might occur to children with adequate immunity against measles. ${ }^{2}$

The milder presentation is also shown by the laboratory examination, where only a small proportion of patients experienced abnormal leukocyte and lymphocyte counts. Theoretically, there would be leukopenia and lymphopenia due to direct immune suppression effect of morbilivirus. ${ }^{2}$ The unusual leucocytosis and lymphocytosis might be explained by secondary bacterial infection, poor nutritional status, or dehydration. ${ }^{21,22}$

\section{CONCLUSION}

This study has described paediatric measles patients with similar clinical presentation with common measles cases. Most of the cases were presented with milder symptoms, signs and laboratory examination. Five cases had complications, but there were no fatalities. However, there is a high prevalence of undernutrition among the subjects, which need further attention from local governments. In addition, there is a concerning high proportion of vaccinated children contracting the disease. This situation needs prompt evaluation from the health authority on vaccination quality and administration procedure.

\section{CONFLICTS OF INTEREST}

The authors declare that they have no conflicts of interest.

\section{REFERENCES}

1. Effendy BSD. Pengaruh reaksi imunisasi campak terhadap sikap dan perilaku ibu dalam pelaksanaan imunisasi campak di Kota Semarang
[Undergraduate Thesis]. Universitas Diponegoro; 2013.

2. Marcdante KJ, Kliegman R, editors. Nelson Essentials of Pediatrics. 7th ed. Philadelphia: Elsevier; 2015.

3. Direktorat Jenderal Pengendalian Penyakit dan Penyehatan Lingkungan. Profil Pengendalian Penyakit dan Penyehatan Lingkungan Tahun 2014. Jakarta; 2015.

4. World Health Organisation. Measles [Internet]. 2017 [cited 2017 Sep 28]. Available from:

http://www.who.int/mediacentre/fa ctsheets/fs286/en/

5. Papadakis MA, McPhee SJ, Rabow MW. Current Medical Diagnosis and Treatment 2014. 53rd ed. Papadakis MA, McPhee SJ, Rabow MW, editors. New York: McGraw-Hill Education; 2013.

6. Pusat Data dan Informasi Kemenkes RI. Profil Kesehatan Indonesia tahun 2016. Jakarta; 2016.

7. Dinas Kesehatan Kabupaten Jombang. Profil Kesehatan Kabupaten Jombang 2016. Jombang; 2017.

8. Nurani DS, Ginanjar P, Saraswati LD. Gambaran Epidemiologi Kasus Campak di Kota Cirebon tahun 2004-2011. J Kesehat Masy. 2012;1(2):293-304.

9. Liwu TS, Rampengan NH, Tatura SNN. Hubungan status gizi dengan berat ringannya campak pada anak. J E-Clin. 2016;4(1):237-42.

10. Ingridara $N$, Garna $H$, Budiman $B$. Hubungan Usia, Status Gizi, dan Status Imunisasi dengan Kejadian Campak pada Anak Usia 0-5 Tahun di Rumah Sakit Umum Daerah AlIhsan Periode Januari 2016-Mei 2017. In: Bandung Meeting on Global Medicine \& Health. Bandung; 2017. p. 49-54.

11. Junawanto I, Goutama IL, Sylvani. Diagnosis dan Penanganan Terkini Bronkiolitis pada Anak. Cermin Dunia Kedokt. 2016;43(6):427-30.

12. Debi N. Karakteristik Balita Penderita Gastroenteritis yang Dirawat Inap di Rumah Sakit Umum Daerah DR. R.M. Djoelham Binjai Tahun 2006. Universitas Sumatera Utara; 2007. 
13. Adriani L. Relationship Between Children Under Five Years Characteristics, Age While Measles Immunization, History of Exclusive Breastfeeding with Clinical Measles. J Berk Epidemiol. 2017;5(2):265-75.

14. Dinas Kesehatan Provinsi Jawa Barat. Profil Kesehatan 2016. Bandung; 2017.

15. Dinas Kesehatan Daerah Provinsi Sulawesi Utara. Profil Kesehatan Provinsi Sulawesi Utara 2016. Manado; 2017.

16. Brown KH. Diarrhea and Malnutrition. J Nutr. 2003 Jan $1 ; 133(1): 328 \mathrm{~S}-332 \mathrm{~S}$.

17. Lestari CSW, Tjitra E, Sandjaja. Dampak Status Imunisasi Anak Balita di Indonesia terhadap Kejadian Penyakit. Media Penelit Dan Pengemb Kesehat. 2009;19(Supplemen 2):S5-12.
18. Hadinegoro SRS, Moedjito I, Hapsari MMDEAH, Alam A. Buku Ajar Infeksi dan Penyakit Tropis. 2nd ed. Jakart: Ikatan Dokter Anak Indonesia; 2008.

19. Carazo S, Billard M-N, Boutin A, De Serres G. Effect of age at vaccination on the measles vaccine effectiveness and immunogenicity: systematic review and meta-analysis. BMC Infect Dis. 2020;20(1):251.

20. Farahdina S, Wulan AJ. Morbili pada anak laki-laki usia 31 bulan dengan riwayat imunisasi campak pada usia 10 bulan. J Medula Unila. 2017;7(1):60-7.

21. Halim RG. Campak pada anak. Cermin Dunia Kedokt. 2016;43(3):186-9.

22. Atmadja AS, Kusuma R, Dinata F. Pemeriksaan Laboratorium untuk Membedakan Infeksi Bakteri dan Infeksi Virus. Cermin Dunia Kedokt. 2016;43(6):457-61. 